\title{
PREVENÇÃO CONTRA INCÊNDIOS EM RESIDENCIAS DE MADEIRA EM ÁREAS RURAIS
}

\author{
Tatiana Bruna Fabian ${ }^{1}$ \\ João Carlos Souza
}

\section{RESUMO}

A arquitetura europeia edificada no estado catarinense se tornou um símbolo da evolução de um povo que, refugiado de sua terra natal, conseguiu se instalar e se desenvolver no Brasil. Hoje, além de ser um símbolo cultural, turisticamente diversas cidades catarinenses possuem sua economia fomentada no turismo das edificações construídas por imigrantes, como é o caso, por exemplo, da arquitetura austríaca de Trezes Tílias, alemã de Blumenau, ou Japonesa de Frei Rogério. Porém um aspecto preocupante se refere a precariedade de algumas residências que, além da deterioração decorrente das intempéries possuem estruturas em madeira que estão suscetíveis a disseminação do fogo em caso de acidente. Um aspecto relevante considerado nesta pesquisa é que, atualmente, há uma grande quantidade de edificações rurais no meio Oeste do estado de Santa Catarina que conservam este tipo de arquitetura. Assim, por instalações elétricas precárias, ou fagulhas de fogo geradas externamente, estas edificações encontram-se vulneráveis a propagação de um incêndio. Com isso o presente trabalho, através de um levantamento bibliográfico, buscou reunir os principais autores que discorrem acerca da temática, enaltecendo soluções viáveis do olhar da arquitetura para potencializar a segurança contra incêndio em casas construídas em madeira para conscientizar, principalmente, a população rural.

Palavras-chave: edificações em madeira; prevenção contra incêndio; arquitetura vernacular; edificações europeias; edificações rurais.

\footnotetext{
${ }^{1}$ Arquiteta e Urbanista. Mestranda do programa PósArq pela Universidade Federal de Santa Catarina. E-mail: arq.tatianafabian@gmail.com

${ }^{2}$ Doutor, Professor e Orientador no Programa de Pós-Graduação em Arquitetura e Urbanismo da Universidade Federal de Santa Catarina. E-mail: joao.carlos@ufsc.br
} 
A European architecture built in the state of Santa Catarina has become a symbol of the evolution of a people who, refugee from their homeland, managed to settle and develop in Brazil. Today, in addition to being a cultural symbol, several cities in Santa Catarina have their economy fostered in the tourism of buildings built by immigrants, as is the case, for example, of Austrian architecture of Treze Tílias, German of Blumenau or Japanese of Frei Rogério. However, a worrying aspect refers to the precariousness of some homes that, in addition to the deterioration resulting from the weather, have wooden structures that are susceptible to the spread of fire in the event of an accident. A relevant aspect considered in this research, currently, there is a large amount of agricultural editions in the midwest of the state of Santa Catarina that conserves this type of architecture. Thus, due to precarious electrical installations, or sparks of fire generated externally, these buildings are vulnerable to the spread of a fire. With this, the present work, through a bibliographic survey, seeks to bring together the main authors who discuss the theme, praising viable solutions of the visual architecture to enhance fire safety in houses built in wood to raise awareness, mainly, a rural population.

Keywords: wooden buildings; fire prevention; vernacular architecture; European buildings; rural building 


\section{INTRODUÇÃO}

A prevenção contra incêndio é um tema que vem adquirindo importância na comunidade da construção civil. Porém, um aspecto que chama a atenção, é que tal relevância só começou a ser constatada depois de desastres ocasionados por situações de incêndio que poderiam ter sido evitadas com medidas preventivas simples. Os incidentes históricos do edifício Andraus e Joelma ilustram claramente a situação da cultura brasileira em relação a este assunto. $\mathrm{O}$ caráter reativo e não preventivo brasileiro, foi o que impulsionou $\mathrm{o}$ surgimento de estudos, normatizações e fiscalizações mais coerentes com a importância da causa.

Desta forma, o presente artigo busca explorar estas premissas, elencando as soluções adequadas para promover medidas de segurança aplicáveis a edificações de madeira rurais, uma vez que, o quantitativo de casas em madeira na região meio Oeste catarinense é significativo. Por terem sido concebidas, em sua maior parte, por imigrantes europeus que chegaram ao meio Oeste catarinense com a construção da estrutura férrea ligaria São Paulo ao Rio Grande do Sul, estas estruturas arquitetônicas, além de abrigar grande patrimônio histórico e cultural, possuem características preocupantes em relação a prevenção contra incêndio, uma vez que, foram edificadas em um período de escassa tecnologia, não levando em consideração estes quesitos. Além disso, com o passar do tempo, tais edificações, seja por falta de manutenção ou ao uso inadequado de seus moradores, principalmente no que se refere a rede elétrica, estão sujeitas facilmente a acidentes e incêndios.

\section{METODOLOGIA}

A metodologia desta pesquisa teve como base as autoras Lakatos e Marconi (2010) em toda a estruturação do trabalho, compreendendo, além 
Revista Científica do Corpo de Bombeiros Militar de Pernambuco

Artigo Publicado no Vol.06 N.17 - Edição Jul a Dez 2020 - ISSN 2359-4829

Versão on-line disponível em: http://www.revistaflammae.com

disso, um caráter exploratório, uma vez que tem como meta proporcionar maior familiaridade da pesquisadora com o problema, visando torná-lo explícito e possibilitando a construção de hipóteses (STRIEDER, 2009), procurando acima disso acumular e sistematizar conhecimentos sobre o tema em estudo para que a sociedade em geral note a real importância da causa.

De modo preliminar foi levantado materiais bibliográficos cujos autores buscavam explanar acerca desta temática. Desta forma, a pesquisa bibliográfica serviu como ponto de partida para a construção do referencial teórico da pesquisa sobre as tipologias de edificações concebidas em madeira, sua importância histórica e as situações que as deixam suscetíveis a propagação de um incêndio, bem como a situação de risco em que se encontram grande parte das residências rurais do estado de Santa Catarina.

Foram realizadas a leitura e a análise de artigos em periódicos e eventos, trabalhos de conclusão de curso, dissertações, normas e legislações vigentes, nacionais e internacionais. Através da leitura de estudos acadêmicos, com visitas de campo/exploratória, foram avaliadas as proposições pertinentes às normas estudadas e desta forma todo o material agregado auxiliou na estruturação e nas conclusões obtidas no presente artigo.

Quanto aos procedimentos classifica-se como bibliográfica - porque "é feito a partir do levantamento de referências teóricas já analisadas, e publicadas por meios escritos e eletrônicos, como livros, artigos científicos, páginas de web sites". (FONSECA, 2002, p. 32). De acordo com Cervo, Bervian e da Silva (2007, p.61), a pesquisa bibliográfica "constitui o procedimento básico para os estudos monográficos, pelos quais se busca 0 domínio do estado da arte sobre determinado tema". Além destas premissas, cabe-se elencar que, o desenvolvimento deste trabalho seguiu as normas estabelecidas pela ABNT (Associação Brasileira de Normas Técnicas). 


\title{
3. REFERÊNCIAL TEÓRICO
}

\section{UMA CONTEXTUALIZAÇÃO SOBRE A CASA DE MADEIRA}

A madeira é a matéria prima natural mais antiga utilizada pelo homem. Depois das cavernas, as construções empregadas com este tipo de material passaram a fazer parte do cotidiano das populações pré-históricas, iniciando com estruturas precárias amarradas com cipós ou até mesmo troncos empilhados cobertos de terra.

\begin{abstract}
Quando se pensa na história da habitação humana, muitas pessoas cometem o erro de considerar que os edifícios de pedra antecederam os de madeira. Contudo, séculos de incêndios e guerras destruíram a maior parte dos edifícios em madeira, deixando apenas os vestígios de pedra. As cicatrizes de cidades de madeira queimadas levaram a que se desenvolvesse mais a tecnologia de trabalhar a pedra nos últimos séculos a.C. As estruturas em pedra encontravam-se, no entanto, praticamente limitadas a grandes edifícios, como templos e palácios, sendo as demais construções construídas em madeira (Cachim, 2008, p.18).
\end{abstract}

No Brasil, o início do emprego da madeira na construção civil está ligado a arquitetura indígena, onde os índios utilizavam estruturas leves de madeira com cobertura de palha para erguer suas ocas. Com o tempo essa arquitetura foi se misturando e até de certa forma sendo dissolvida pelo modo de edificar dos imigrantes europeus que aqui chegavam.

A região Sul, juntamente com o Nordeste brasileiro, são as regiões que mais possuem história com edificações em madeira desde a época da colonização. De acordo com Bogo (2017) na região Sul do Brasil, a utilização de habitações em madeira está incorporada à arquitetura de inúmeras populações urbanas e rurais, principalmente no Rio Grande do Sul e em Santa Catarina. A utilização de habitações em madeira em Santa Catarina é originária ao período da colonização do estado pelos imigrantes alemães, italianos, eslavos, entre outros, a partir de meados do século 19 e início do século 20, principalmente no Vale do Itajaí, Planalto Serrano (Sul e Norte), Meio-Oeste e 
Revista Científica do Corpo de Bombeiros Militar de Pernambuco

Artigo Publicado no Vol.06 N.17 - Edição Jul a Dez 2020 - ISSN 2359-4829

Versão on-line disponível em: http://www.revistaflammae.com

Oeste catarinense, existindo ainda hoje no estado uma forte economia baseada na madeira. Também no litoral catarinense, de colonização açoriana, identificase a tipologia de casas em madeira em grande escala, sobretudo para atendimento as populações de baixa renda.

O mesmo autor ainda enaltece o motivo pelo qual as edificações em madeira foram tão importantes para os primeiros imigrantes. Este material existia em abundância, e em boa qualidade (madeiras nobres), o que acabou impulsionando a economia entorno da extração e beneficiamento, tornando o setor madeireiro um dos pilares que move a economia de Santa Catarina até os dias atuais.

A Tabela 1, ilustra o percentual de domicílios concebidos em madeira existentes nos estados do Sul do Brasil no ano de 2017.

Tabela 1 - Percentual das residencial em madeira existente no sul do Brasil

\begin{tabular}{|l|c|}
\hline Estados do Sul & Percentual de domicílios ${ }^{\star}$ de madeira \\
\hline Rio Grande do Sul & 29,10 \\
\hline Santa Catarina & 28,20 \\
\hline Paraná & 25,98 \\
\hline Média Nacional & 9,10 \\
\hline
\end{tabular}

Fonte: Bogo (2017)

Desta forma é possível verificar que nos três estados do Sul do Brasil (PR, SC e RS), o percentual de domicílios de madeira supera a média nacional de $9,10 \%$, com os valores de $28,20 \%$ em Santa Catarina. Neste estado, nas regiões do Planalto Serrano, Meio-Oeste, Planalto Norte e Oeste, apresentam forte tradição madeireira, possuindo os municípios com os maiores percentuais (Bogo, 2017). A Tabela 2 traz estes parâmetros quantitativos. 


\section{Revista FLAMMAE}

Revista Científica do Corpo de Bombeiros Militar de Pernambuco

Artigo Publicado no Vol.06 N.17 - Edição Jul a Dez 2020 - ISSN 2359-4829

Versão on-line disponível em: http://www.revistaflammae.com

Tabela 2 - Percentual de edificações de madeira no estado de Santa Catarina

Cidades que possuem maior concentração de edificações em madeira em SC Município e Região de Santa Catarina Percentual de domicílios em Madeira Curitibanos - Planalto Serrano

Caçador - Meio Oeste $56,28 \%$

Porto União - Planalto Norte $44,78 \%$

Mafra - Planalto Norte $44,07 \%$

Canoinhas - Planalto Norte $42,68 \%$ Chapecó - Oeste $41,54 \%$ Concórdia - Oeste $33,86 \%$ Tubarão - Litoral Sul $33,25 \%$ Videira - Meio Oeste $32,97 \%$ $30,36 \%$ $28,72 \%$ $28,22 \%$ $25,59 \%$ $20,33 \%$

Rio do Sul - Alto Valor do Itajaí

Fonte: Bogo (2017)

Os dados enaltecem que as edificações em madeira merecem sim atenção, tanto em relação a sua preservação, quanto na questão da prevenção contra princípios de incêndio que nelas podem ocorrer. Em relação a sua preservação, constata-se que o patrimônio histórico-arquitetônico destas edificações vernaculares em madeira de Santa Catarina ainda é pouco protegido. Na lista de edificações que contém os conjuntos e núcleos tombados em nível federal pelo Iphan no estado, poucas são de edificações em madeira. Dos dez municípios de Santa Catarina com maior percentual de domicílios de madeira, somente um, Videira, em nono lugar da lista, possui uma edificação em madeira tombada em nível estadual, que é o museu do vinho Mário de Pellegrin, concebido pela imigração alemã que se instalou na região meio Oeste por volta da década de 30 (Bogo, 2017). 


\section{Revista FLAMMAE}

Revista Científica do Corpo de Bombeiros Militar de Pernambuco

Artigo Publicado no Vol.06 N.17 - Edição Jul a Dez 2020 - ISSN 2359-4829

Versão on-line disponível em: http://www.revistaflammae.com

Figura 1 - Museu do Vinho Mário de Pellegrin (Videira/SC)

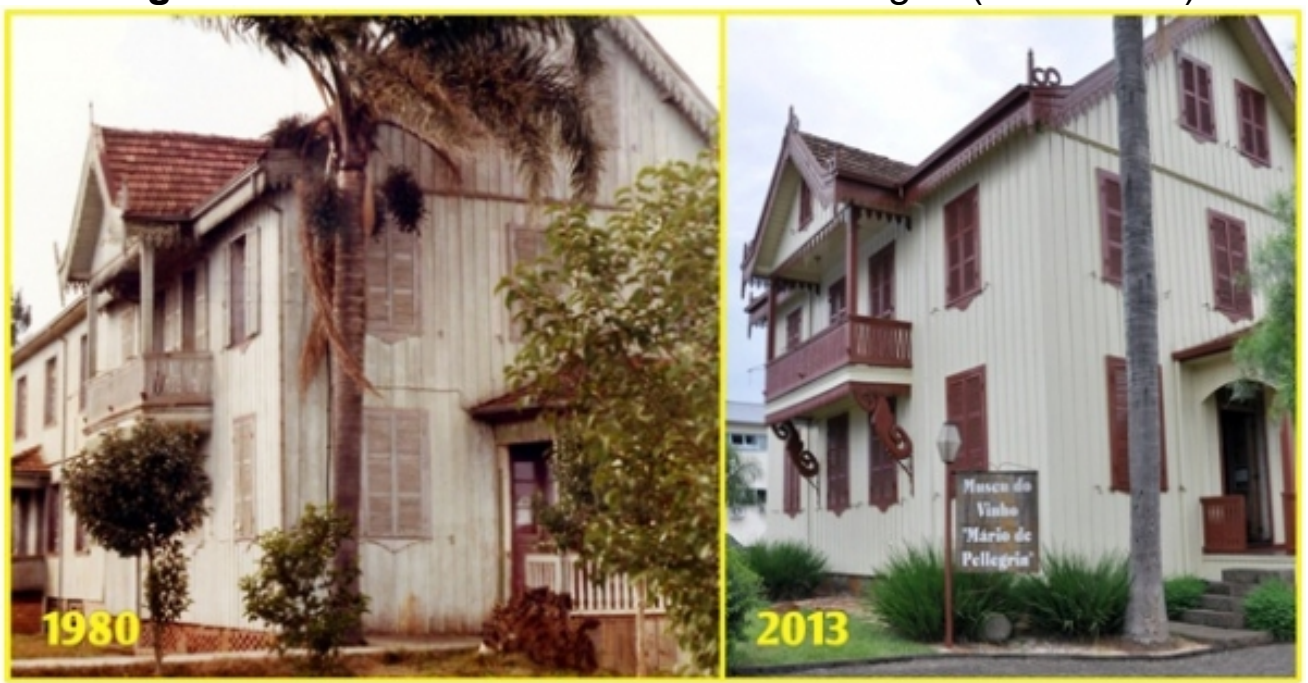

Fonte: Fundação catarinense da cultura (2013)

Um dos apectos que influenciam o abandono deste tipo de material construtivo se refere ao desconhecimento das propriedades da madeira, que por métodos de construção antiquados, acabam proporcionando a edificação um desempenho instisfatório. Devido as suas características próprias, que exigem constante manutenção, grande parte das edificações antigas de maior porte em madeira foram abandonadas ou já demolidas, em decorrência do processo de "modernização" das formas de viver e morar, mais intenso no estado a partir da década de 1970. Deste modo, nas áreas centrais de muitas cidades pólos de Santa Catarina, os antigos conjuntos de edificações em madeira existentes para diferentes usos foi sendo substituído progressivamente. No entanto, para boa parte da população catarinense, morar em casas de madeira continuou a ser uma constante, pela base econômica madeireira existente em muitas regiões do estado e pelo menor custo de aquisição, fator este decisivo para as populações de baixa renda.

Desta forma a pesquisa em questão busca enaltecer a importância de se discutir esta causa, buscando medidas de conscientização para a população rural acerca do assunto, preservando não somente bem materiais mas sim a integridade física de seus moradores. Além disso preza por medidas para 
ampliar a participação da madeira no cenário da construção civil de modo coerente, explorando suas melhores qualidades em prol da segurança contra possíveis incêndios.

\section{PRINCIPAIS FOCOS DE INCÊNDIO EM CASAS DE MADEIRA EM ÁREAS RURAIS}

O fogo é útil e necessário à humanidade. Porém, fora de controle vira incêndio. Para compreender como ocorrem os incêndios e as medidas mais adequadas para proteger as edificações contra este tipo de sinistro, é necessário previamente buscar conhecer os aspectos básicos que norteiam o conceito do fogo, desde os motivos que resultam em sua ignição, até os elementos correlacionados a sua propagação e extinção.

O fogo é definido como um processo químico de transformação. Seria a ocorrência de uma reação exotérmica autossustentada que resulta da combinação de um agente combustível com um oxidante, que desprende como resultado gases, luz e calor (ANVISA, 2011 apud Coté, 2002). Desta forma, para que o fogo consiga existir é necessária a coexistência simultânea de quatro elementos, que juntos representados de uma maneira didática, formam o conhecido "tetraedro do fogo". Estes elementos seriam o combustível, comburente (normalmente o oxigênio), calor e a reação em cadeia conforme ilustrado na Figura 2. 


\section{Revista FLAMMAE}

Revista Científica do Corpo de Bombeiros Militar de Pernambuco

Artigo Publicado no Vol.06 N.17 - Edição Jul a Dez 2020 - ISSN 2359-4829

Versão on-line disponível em: http://www.revistaflammae.com

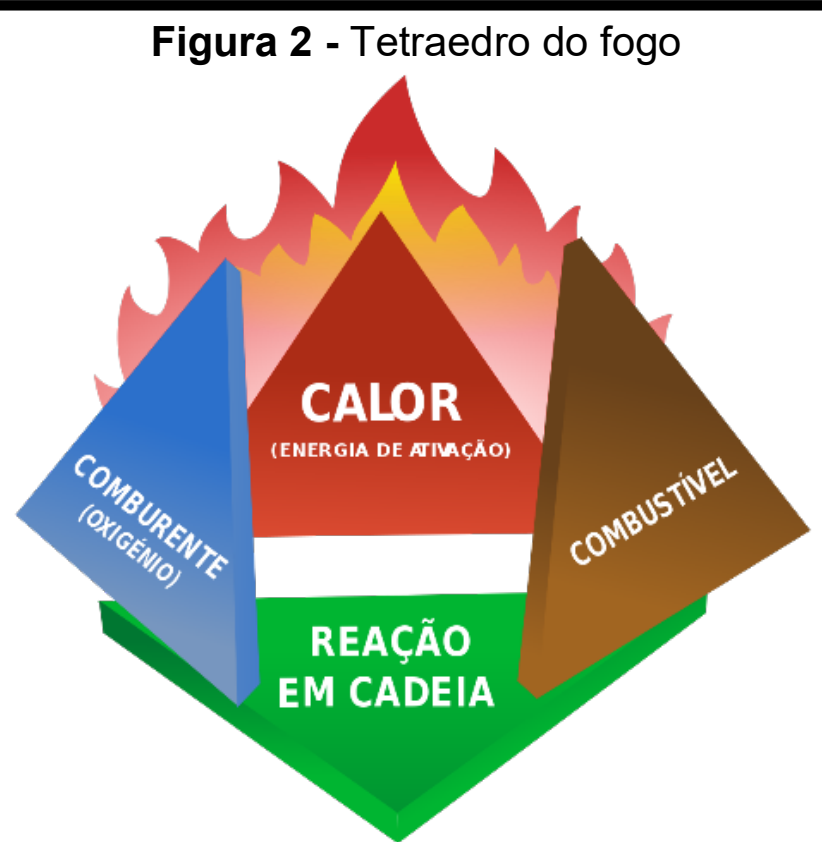

Fonte: Dietrich (2015)

Desta forma o termo incêndio se relaciona ao fogo em um estado de disseminação descontrolado no tempo e espaço, causando danos muitas vezes irreversíveis e prejuízos à vida, ao patrimônio edificado e ao meio ambiente. Seito (2008) descreve que o crescimento do fogo “(...) dependerá do primeiro item ignizado, das características do comportamento ao fogo dos materiais na proximidade do item ignizado e sua distribuição no ambiente."

A propagação de um incêndio é dividida em fases. Estas fases são definidas de modo geral como: Ignição, crescimento, Flash over, Pós Flash over e extinção, conforme ilustrado na Figura 3. 
Revista Científica do Corpo de Bombeiros Militar de Pernambuco

Artigo Publicado no Vol.06 N.17 - Edição Jul a Dez 2020 - ISSN 2359-4829

Versão on-line disponível em: http://www.revistaflammae.com

Figura 3 - llustrativo das fases de um incêndio

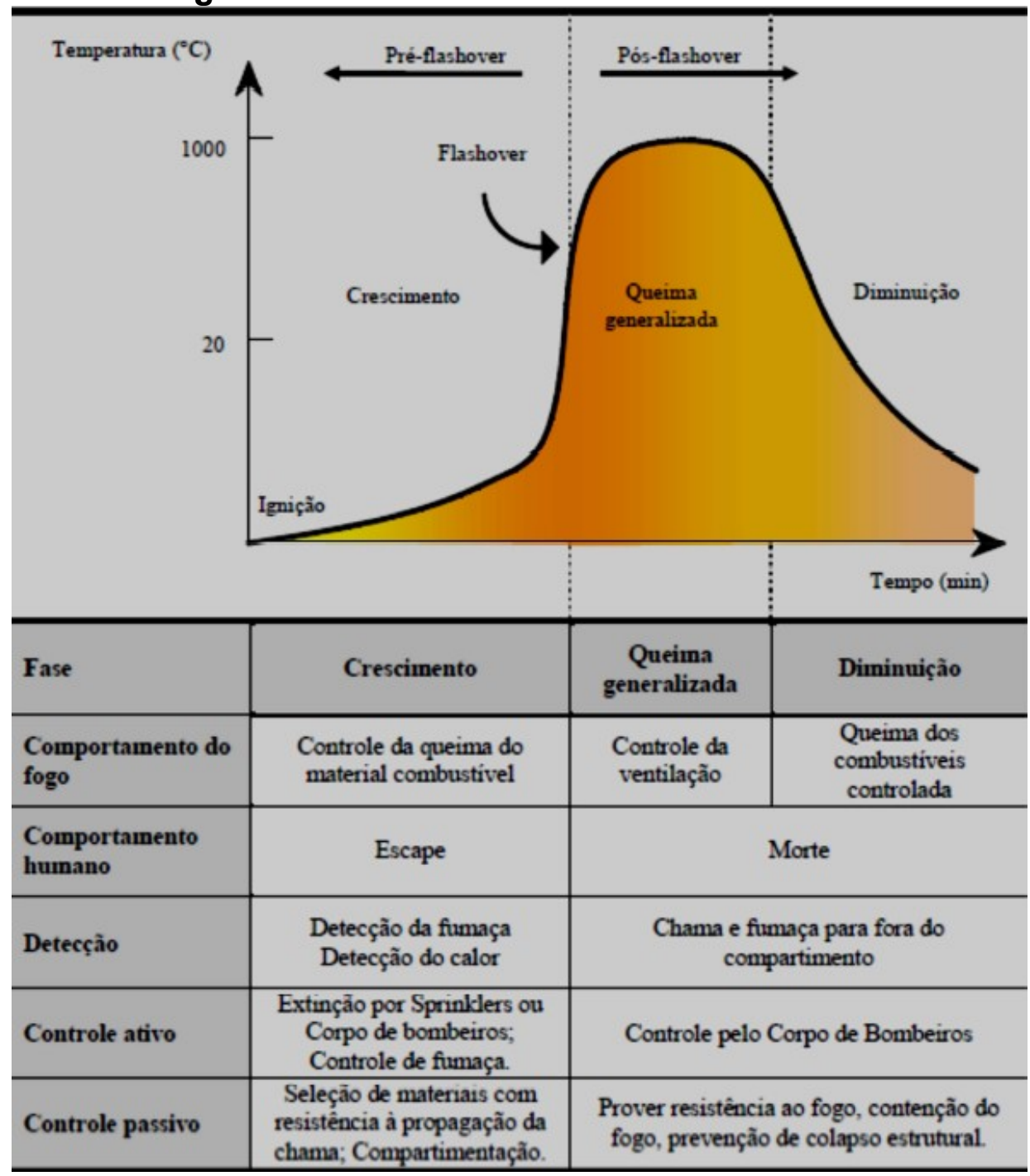

Fonte: Hurtado, 2013 apud Bonitese (2007)

A primeira fase de crescimento do fogo é entendida como a ignição, que seria a situação em que os quatro elementos do quadrilátero de fogo se unem e dão início à combustão. O início deste processo é descrito da seguinte maneira pela Anvisa:

Num primeiro estágio do incêndio, verifica-se uma fase de latência (pré-ignição), ou seja, a combustão muito lenta, com pouca produção de calor e baixa emissão de gases combustíveis e fumaça. Esse primeiro estágio, em casos muito particulares, pode durar até horas. Ainda nessa etapa, verifica-se a efetiva deflagração de chama aberta 


\section{Revista FLAMMAE}

Revista Científica do Corpo de Bombeiros Militar de Pernambuco

Artigo Publicado no Vol.06 N.17 - Edição Jul a Dez 2020 - ISSN 2359-4829

Versão on-line disponível em: http://www.revistaflammae.com

(ou ignição). Destaca-se que nesse estágio, a movimentação da fumaça ainda é muito pequena e deve-se exclusivamente ao fluxo de ar ambiente, resultando em grande dificuldade de percepção (ANVISA, 2011, p. 17).

$\mathrm{Na}$ fase posterior, por sua vez, verifica-se o crescimento do incêndio e sua propagação para objetos adjacentes ou ainda para a cobertura ou teto do ambiente. Percebe-se o aumento significativo da temperatura, com grande geração de fumaça e calor, ocasionada pela disseminação das chamas. Este crescimento acaba desencadeando do Flash over.

O Flash over é definido por Hurtado como:

A transição entre a fase de crescimento e a queima generalizada do incêndio. Durante o flashover, as condições no compartimento mudam rapidamente, em função de um aumento da radiação e temperatura, dada pela contínua combustão e pela queima dos primeiros materiais inflamados que envolvem todas as superfícies combustíveis expostas no interior do compartimento (HURTADO, 2011, p. 11).

Em um ambiente com oxigênio em abundância, a inflamação generalizada ocorre em um tempo máximo de 20 minutos após o início do incêndio (Anvisa apud Martin e Peris, 1982). Após a inflamação generalizada tem-se o incêndio desenvolvido, ou terceiro estágio, quando todos os materiais combustíveis do ambiente entrarão em combustão (Seito et al., 2008) e provavelmente haverá propagação por meio das aberturas internas, fachadas e cobertura.

$\mathrm{Na}$ terceira fase (pós flash over), a reação ao fogo dos elementos construtivos e de acabamento é que define a velocidade de alastramento do incêndio. Em seguida vem o quarto e último estágio, ou extinção do fogo, quando esse diminui de intensidade em razão da redução da disponibilidade de material combustível para queima.

A transmissão do calor durante o incêndio pode ocorrer de três maneiras: por condução, convecção e irradiação. A primeira se caracteriza pela transmissão do calor através do próprio material, de molécula a molécula ou de 
Revista Científica do Corpo de Bombeiros Militar de Pernambuco

Artigo Publicado no Vol.06 N.17 - Edição Jul a Dez 2020 - ISSN 2359-4829

Versão on-line disponível em: http://www.revistaflammae.com

corpo a corpo. A convecção, se ilustra quando o calor se transmite através de uma massa de ar aquecida, que se desloca do local em chamas, levando para outros locais quantidade de calor suficiente para que os materiais combustíveis aí existentes atinjam seu ponto de combustão, originando outro foco de fogo. $\mathrm{E}$ por fim a irradiação é quando o calor se transmite por ondas caloríficas através do espaço, sem utilizar qualquer meio material. A Figura $4(a, b, c)$ ilustra o descrito.

Figura 4 - Formas de propagação de um incêndio

a) Condução
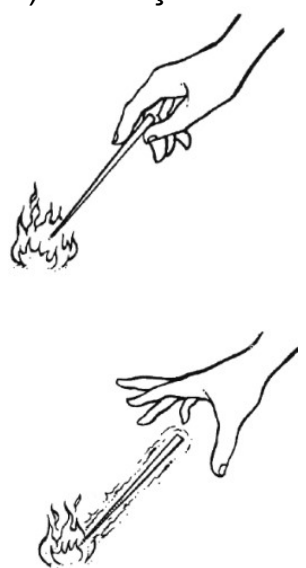

b) Convecção

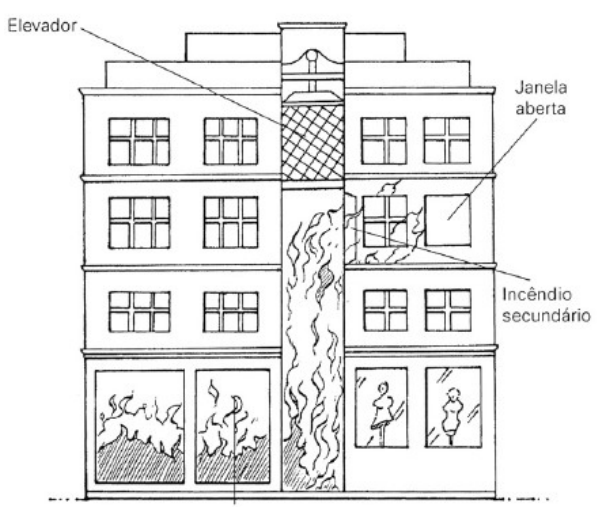

c) Irradiação
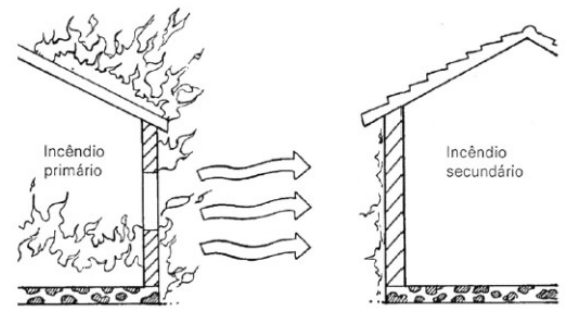

Fonte: Costa (2016) adaptado pela autora (2020)

A Anvisa descreve que "quanto mais rápida a intervenção para controlar e extinguir o incêndio, maior a probabilidade de sucesso da ação, ao mesmo tempo em que menores serão os recursos necessários para o combate às chamas e os prejuízos advindos do incidente (ANVISA, 2011, p.19)." Desta forma

A extinção do incêndio se dá através de uma ação para romper o tetraedro do fogo. Eliminando-se qualquer um dos quatro elementos essenciais para a manutenção do fogo, interrompe-se o processo de combustão e, consequentemente, o incêndio. Assim, pode-se eliminar, afastar ou bloquear o combustível (isolamento), embora isso nem sempre seja possível. Pode-se reduzir, eliminar ou afastar o comburente (oxigênio), por abafamento ou pela sua substituição por outro gás não comburente (inerte). Pode-se eliminar o calor através do resfriamento no ponto em que ocorre a queima ou combustão ou, ainda, pode-se interromper a reação em cadeia (ANVISA, 2011, p. 19). 
Revista Científica do Corpo de Bombeiros Militar de Pernambuco

Artigo Publicado no Vol.06 N.17 - Edição Jul a Dez 2020 - ISSN 2359-4829

Versão on-line disponível em: http://www.revistaflammae.com

O descrito anteriormente é ilustrado na Tabela 3, com os procedimentos que devem ser realizados para promover a interrupção de um incêndio com base no tetraedro do fogo.

Tabela 3 - Extinção do incêndio através do rompimento do tetraedro de fogo

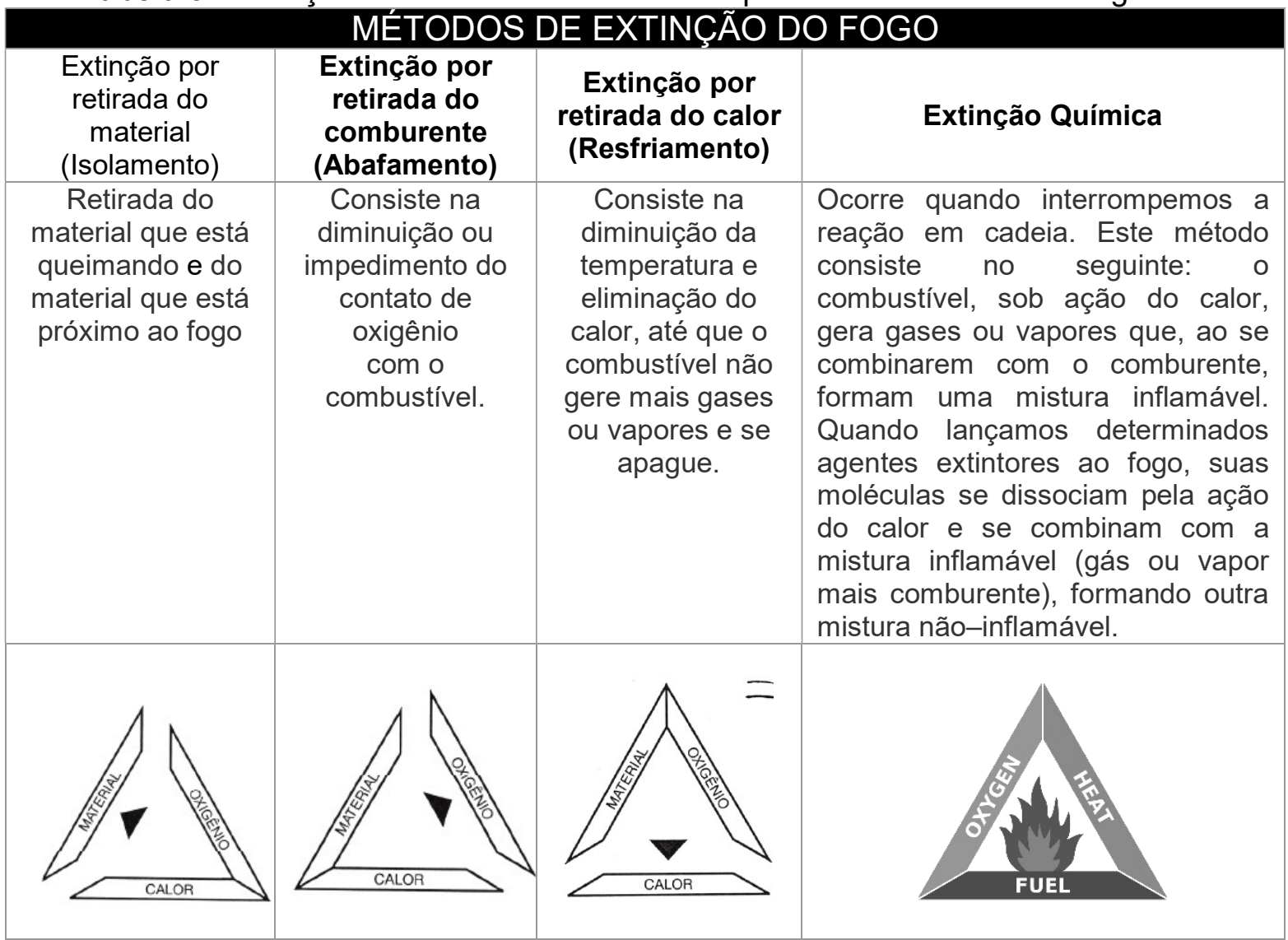

Fonte: CBMSP (2017) adaptado pela autora (2020).

Desta forma verifica-se que é fundamental conhecer o comportamento dos materiais construtivos, dos materiais de revestimento e dos acabamentos em relação ao fogo. Uma edificação segura contra incêndio é aquela adequadamente projetada, executada e mantida a fim de minimizar a probabilidade do início de um incêndio, mas na eventualidade da ocorrência do mesmo, há alta probabilidade de que todos os ocupantes sobrevivam sem sofrer qualquer ferimento (Anvisa, 2011 adaptado de Harmathy, 1984). 
Revista Científica do Corpo de Bombeiros Militar de Pernambuco

Artigo Publicado no Vol.06 N.17 - Edição Jul a Dez 2020 - ISSN 2359-4829

Versão on-line disponível em: http://www.revistaflammae.com

Como protagonistas dos princípios de incêndio, três elementos merecem atenção em edificações de tipologia residencial, principalmente em madeira: a eletricidade, gás e água. A água, na hora de combater as chamas, deve estar sempre disponível e, em construções vernaculares pode comprometer a casa durante um caso de sinistro, devido ao peso distribuído sobre a estrutura. Quando se tem gás inflamável, também basta uma centelha para iniciar o fogo, podendo levar a explosões. Logo é possível que, se ocorrer vazamentos de gás, danos estruturais também poderão existir inutilizando a edificação. Nessa condição, quase nada poderá ser feito.

A prevenção de incêndio, desta forma, se refere ao conjunto de medidas que visam: evitar o incêndio; dificultar sua propagação; proporcionar meios de controle e extinção do incêndio, analisando as possíveis causas e efeitos para formular e produzir soluções para as mesmas (Carnielletto et al, 2019).

Silva (2018) ainda enfatiza a necessidade de enaltecer essa preocupação com a prevenção contra incêndio nas casas típicas da arquitetura vernacular imigratória edificada em Santa Catarina. O mesmo exalta que

(...) é grande a dificuldade para combater incêndios em edificações construídas numa época em que não havia preocupação com este tipo de risco. Adicione a isso fatores como utilização de materiais de queima fácil empregados na construção e a geometria da edificação. Outro problema presente, principalmente nas cidades coloniais, é a dificuldade de tráfego e de acesso ao local durante ocorrência do incêndio. Na grande maioria, só se tem acesso às fachadas que dão frente para a rua. Essa característica dificulta o combate às chamas e a evacuação das pessoas que estiverem dentro da edificação. Além disso a falta de espaço entre as construções permite que o fogo passe às construções adjacentes. Tal situação pode levar a um grave caso de sinistro (SILVA, 2018, p.23).

Para Freire (2009), esta situação ainda é intensificada pelo mau uso das habitações por seus moradores, uma vez que sobrecargas na rede elétrica ou pequenas fagulhas geradas por um fogão esquecido aceso podem ocasionar uma grande catástrofe. Dessa maneira várias são as situações em que se pode gerar um cenário propício para ignição de um incêndio. Seito (2008), descreve as principais causas de incêndio nas edificações desta tipologia. 
Alguns exemplos de início de ignição são: vazamento de gás de bujões com explosões, curto-circuito em instalações elétricas por excesso de carga, manuseio de explosivos e outros produtos perigosos em locais não adequados, esquecimento de ferro de passar roupa, fogões e eletrodomésticos ligados, etc (SEITO, 2008. p. 12).

O principal elemento desencadeador da maioria dos incêndios, é a eletricidade, principalmente pelo mau uso e pela falta de cuidado. Quando a rede elétrica está funcionando acima de sua capacidade, aumentam as perdas por dissipação de calor, elevando a temperatura. Isto pode provocar uma ignição (Silva, 2018). Nas fotografias representadas na Figura 5 é possível se observar algumas situações que podem servir como estopim para uma eventualidade, e criar chamas que em minutos podem consumir uma edificação em madeira.

Figura 5 - Exemplos de instalação elétrica precária

a) Fiação exposta

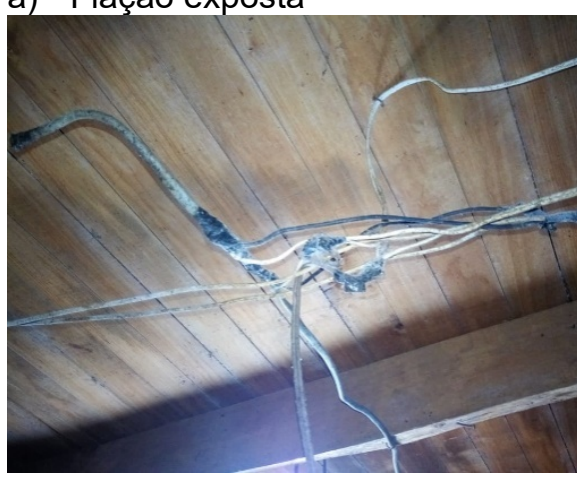

Fonte: os autores (2019) b) Isolamento entre os fios ruim

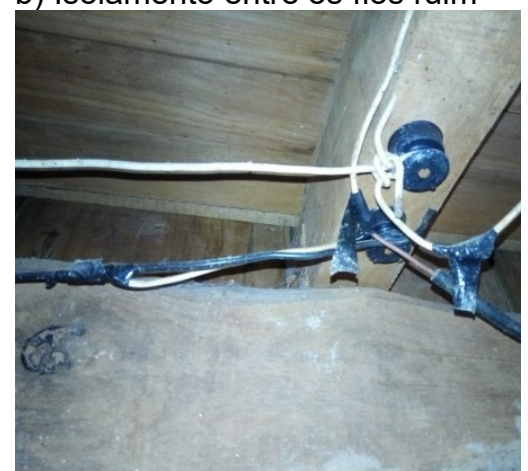

c) Sobrecarga

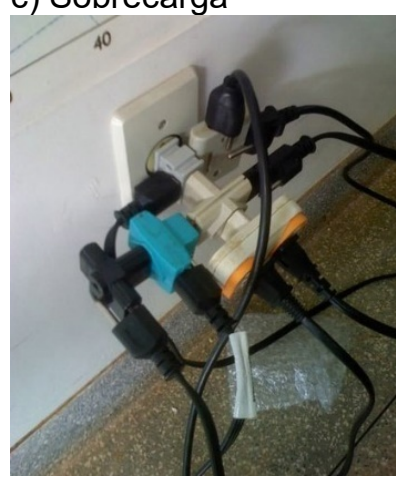

Desta forma cabe-se elencar que as principais combinações, de acordo com o material bibliográfico levantado, que acabam gerando focos de incêndio em edificações em áreas rurais, são estas descritas na Tabela 4 abaixo. 
Revista Científica do Corpo de Bombeiros Militar de Pernambuco

Artigo Publicado no Vol.06 N.17 - Edição Jul a Dez 2020 - ISSN 2359-4829

Versão on-line disponível em: http://www.revistaflammae.com

Tabela 4 - Princípios de incêndio externos a edificação

FATORES EXTERNOS QUE PODEM ATINGIR A EDIFICAÇÃO

\begin{tabular}{cl}
\hline Foco do incêndio (Motivo) & \multicolumn{1}{c}{ Descrição } \\
\hline & Muitos criadores de gado e de outros animais \\
& costumam queimar o pasto para os animais \\
Queima para a rebrota de pastagens & comerem a rebrota. A área queimada pode ser \\
& tanto um pasto plantado, quanto uma área nativa, e \\
& uma vez descontrolada por atingir as edificações \\
& mais próximas.
\end{tabular}

Se refere a prática de queimar a vegetação para eliminar plantas nativas e abrindo espaço livre para o plantio da lavoura. É adotada por alguns povos

Queima para plantios indígenas, pequenos e médios agricultores e grandes fazendeiros, mesmo que essa forma de preparar o terreno para plantio enfraqueça a terra. Este tipo de queimada, uma vez descontrolada, também pode atingir as edificações próximas.

Indivíduos que atuam por vingança ou outro motivo impulsionado pela raiva, como foi o caso da tragédia do Gran Circo Norte-Americano ocorrido

Vandalismo em Niterói, em 17 de dezembro de 1961, em que morreram 503 pessoas, e mais de 800 sofreram ferimentos.

\section{Queima de lixo}

Causa acidental
Por mais que a queima de lixo seja proibida, ainda é uma prática realizada por alguns agricultores. Uma vez descontrolado este foco de incêndio, pode atingir as edificações do entorno.

Alguns incêndios têm causa acidental, como, por exemplo, incêndios causados por fagulhas de máquinas e de grandes veículos ou pelo rompimento de cabos de eletricidade, ou até mesmo raios que atingem vegetações secas presentes no entorno.

Fonte: Arruda (2009) adaptado pelos autores

Além destas, algumas situações podem ocorrer também no interior da residência, como são os casos descritos na Tabela 5 a seguir. 
Revista Científica do Corpo de Bombeiros Militar de Pernambuco

Artigo Publicado no Vol.06 N.17 - Edição Jul a Dez 2020 - ISSN 2359-4829

Versão on-line disponível em: http://www.revistaflammae.com

Tabela 5 - Princípios de incêndio gerados no interior da casa

FATORES INTERNOS QUE PODE GERAR INCÊNDIO

\begin{tabular}{|c|c|}
\hline Velas em rituais religiosos & $\begin{array}{l}\text { Alguns rituais são feitos com o uso de velas } \\
\text { para oração no interior da casa. Fagulhas } \\
\text { originadas da centelha destas velas utilizadas } \\
\text { para oração frente a imagens de santos } \\
\text { podem resultar em um incêndio de maiores } \\
\text { proporções. }\end{array}$ \\
\hline Instalação elétrica precária & $\begin{array}{l}\text { Instalação com isolamento já ultrapassado, } \\
\text { fios desencapados, ou sobrecarga da rede } \\
\text { pode gerar um curto circuito e gerar uma } \\
\text { fagulha de fogo. }\end{array}$ \\
\hline Explosão de gás & $\begin{array}{l}\text { Instalações malfeitas/precárias, sem as } \\
\text { medidas básicas de segurança } \\
\text { recomendadas. }\end{array}$ \\
\hline
\end{tabular}

Fonte: Arruda (2009) adaptado pelos autores

Desta forma cabe aos conhecedores acerca do assunto, buscar disseminar estas situações para a sociedade em geral, principalmente para a população residente na área rural, para buscar amenizar e prevenir possíveis danos causados por um incêndio. Estas regiões, por geralmente se localizarem longe dos perímetros urbanos, demandam um tempo de deslocamento significativo para a chegada do corpo de bombeiros, o que torna esta situação ainda mais delicada. Assim a pesquisa em questão busca conscientizar essa população do risco a qual podem estar sujeitas e incentivá-las e prevenir esta possível ameaça.

\section{COMO PREVENIR O INCÊNDIO EM RESIDÊNCIAS DE MADEIRA}

Vários são os fatores que podem aumentar o risco inicial da combustão em edificações concebidas em madeira. Estas premissas então relacionadas ao tempo de dissipação do fogo que possui relação direta com a espécie da madeira utilizada, seu teor de umidade, a temperatura da fonte de calor, a duração da exposição, o tamanho e forma da madeira e os detalhes construtivos empregados na residência (Pinto, 2001). Para isso cabe-se ter conhecimento acerca das medidas de prevenção contra incêndio que envolvem 
Revista Científica do Corpo de Bombeiros Militar de Pernambuco

Artigo Publicado no Vol.06 N.17 - Edição Jul a Dez 2020 - ISSN 2359-4829

Versão on-line disponível em: http://www.revistaflammae.com

a prevenção, detecção, contenção e evacuação. A principal atitude é a prevenção onde se busca, basicamente, evitar a ignição dos materiais combustíveis pelo controle tanto da fonte de calor como do material combustível. Tal primazia está diretamente relacionada a manutenção devida da edificação em intervalos de tempo regulares e ao conhecimento do tipo de material que foi empregado.

Desta forma a prevenção contra incêndios envolve aspectos materiais e culturais, que vão desde a conscientização dos usuários, controle dos materiais, controle das fontes de calor, tratamento da madeira até o adequado dimensionamento e manutenção das instalações elétricas (Pinto, 2001). Diante do que foi levantado, a Tabela 6 relaciona as principais medidas que devem ser adotadas em uma residência de madeira, principalmente nas mais antigas edificadas pelos primeiros imigrantes que ainda resistem ao tempo, para impedir que problemas relacionados ao fogo ocorram.

Tabela 6 - Medidas atuantes na prevenção

PREVENÇÃO CONTRA INCÊNDIO EM RESIDÊNCIAS EM MADEIRA DA ÁREA RURAL

\begin{tabular}{c} 
Educação / \\
Conscientização \\
acerca do assunto \\
\hline \\
Construção de aceiros \\
\hline $\begin{array}{c}\text { Reciclagem e } \\
\text { reaproveitamento do } \\
\text { lixo }\end{array}$ \\
\hline
\end{tabular}

Tratamento da Madeira da edificação

É preciso sempre aprender e ensinar sobre as causas, as consequências e as formas de evitar os incêndios. Seja através de cartilhas ou de palestras promovidas por profissionais da área nestas comunidades. É preciso sempre alertar e orientar todas as pessoas, adultas ou crianças, e incentivar a instalação de extintores de incêndio em locais onde o risco de incêndio é elevado dentre outras medidas.

Se trata de uma faixa de terreno sem vegetação que impede a propagação do fogo. Um aceiro deve estar completamente roçado (com largura mínima de 3 metros). Um aceiro pode ser uma estrada. É importante lembrar que os aceiros precisam estar sempre em manutenção, ou seja, é preciso que eles estejam sempre capinados, pois, assim, o fogo não se propaga por falta de vegetação para queimar. Desta forma no caso de um foco de incêndio externo a edificação, a existência de aceiros em seu entorno pode impedir que o fogo de alastre da vegetação até a residência.

Não queimar resíduos sólidos no entorno da edificação. A reciclagem ou mesmo a deterioração para adubação são muito mais viáveis, e também não geram fagulhas que, em contato com plantas secas, podem gerar um foco de incêndio.

É uma medida preventiva pode ser idealizada por meio de tintas (recobrimento) e impregnantes. O princípio do tratamento se baseia no conhecimento de que a temperaturas abaixo de $200{ }^{\circ} \mathrm{C}$, a redução da degradação térmica da madeira é geralmente obtida por isolamento da madeira ou fonte de calor. Acima de $200{ }^{\circ} \mathrm{C}$, o processo de degradação termina por pirólise, combustão flamejante e combustão incandescente, estão sujeitos a inibição ou alteração da atuação através de produtos químicos adequados, os produtos ignífugos. A madeira tratada desta forma 
Revista Científica do Corpo de Bombeiros Militar de Pernambuco

Artigo Publicado no Vol.06 N.17 - Edição Jul a Dez 2020 - ISSN 2359-4829

Versão on-line disponível em: http://www.revistaflammae.com

não deve propagar chamas ou contribuir para a sua própria combustão, quando exposta as altas temperaturas, deve apenas carbonizar até se decompor. Este tratamento é utilizado com a finalidade de reduzir os efeitos prejudiciais do fogo na madeira. Foi originalmente criado pelos Romanos no primeiro século antes de Cristo, os quais usavam vinagre e alúmen para retardar o crescimento das chamas. Na Europa, tratamentos retardantes de fogo foram objetos de considerável experimentação entre 1625 e 1800.

Instalação de extintores de incêndio
Em edificações de madeira, a instalação deste tipo de equipamento aumenta a condição de segurança dos moradores e da propriedade, através do combate rápido de um eventual foco de incêndio, impedindo assim que ele tome grandes proporções resultando em perdas maiores ou possibilitando o controle do incêndio até a chegada da equipe de bombeiros.

\section{Revisão e reestruturação da rede elétrica}

O curto circuito é uma das principais causas de incêndio em edificações de madeira. Neste tipo de edificação é imprescindível que a fiação elétrica esteja afastada do contato direto com as superfícies de madeira, através do uso de condutores elétricos com auto extinção ao fogo, evitando que o aquecimento da fiação ou um possível curto circuito provoque combustão da madeira. Além disso deve-se verificar se o dimensionamento das instalações está funcionando de maneira devida.
Sistema de alarme e de detecção de fumaça e fogo

A utilização de sistemas de alarme e detecção de fumaça e fogo em edificações residenciais no Brasil não é uma prática comum. Porém considerando a suscetibilidade da ignição da madeira, este recurso poderia ser adotado neste tipo de edificação. No Canadá, por exemplo, alarmes de incêndio são requeridos em edificações de ocupação residencial quando estas apresentarem mais de 10 pessoas residentes.

Fonte: Pinto (2001) adaptado pelos autores

Diante do que foi exposto constata-se que realmente é válido refletir acerca desta questão para impedir que problemas futuros ocorram. As medidas de prevenção apresentadas acima, em grande parte delas, não possuem dificuldade de execução, sendo desta forma, possível tomar medidas preventivas mesmo em edificações existentes e de certa forma antigas, impedindo danos físicos e materiais posteriores.

\section{O EMPREGO DA MADEIRA EM PROL DA PREVÊNÇÃO CONTRA INCÊNDIO EM EDIFICAÇOES RESIDENCIAIS HOJE}

A madeira é um material versátil, além de esteticamente atraente, essa matéria-prima reduz o tempo de montagem, tem preço competitivo e é durável e segura em caso de incêndio, porque, embora seja combustível, resiste ao 
fogo por um longo período. Pode ser considerada, ainda, uma alternativa sustentável, pois a madeira legalizada para o uso na construção é extraída de florestas regulamentadas pelo Ibama (Instituto Brasileiro do Meio Ambiente e dos Recursos Naturais Renováveis), o que significa que todas as árvores são identificadas e que a área é reflorestada. $O$ órgão também é responsável pelo DOF (Documento de Origem Florestal), que garante 0 rastreamento do momento da extração até a entrega na obra. Outro item que garante a sustentabilidade são os certificados, como o (certificado) 'Madeira Legal', entre tantos outros, que indicam a origem da espécie.

Atualmente as novas tecnologias construtivas e novas formas de tratamento da madeira possibilitaram com que a madeira voltasse ao mercado da construção civil por meio de sistemas como o Wood Frame, por exemplo. Este é composto por perfis de madeira estruturados, formando placas vazadas que são posteriormente fechadas por painéis de vedação, normalmente de OSB. Os perfis são feitos com madeira de reflorestamento, o que contribui para que o processo seja considerado ecológico. Este sistema construtivo de estrutura em madeira é largamente utilizado na construção de casas no Canadá, Estados Unidos, Suécia e Alemanha. O baixo impacto ambiental, o custo reduzido e a durabilidade comparável ao sistema em alvenaria são alguns dos responsáveis pela popularidade do Wood Frame pelo mundo. 


\section{Revista FLAMMAE}

Revista Científica do Corpo de Bombeiros Militar de Pernambuco

Artigo Publicado no Vol.06 N.17 - Edição Jul a Dez 2020 - ISSN 2359-4829

Versão on-line disponível em: http://www.revistaflammae.com

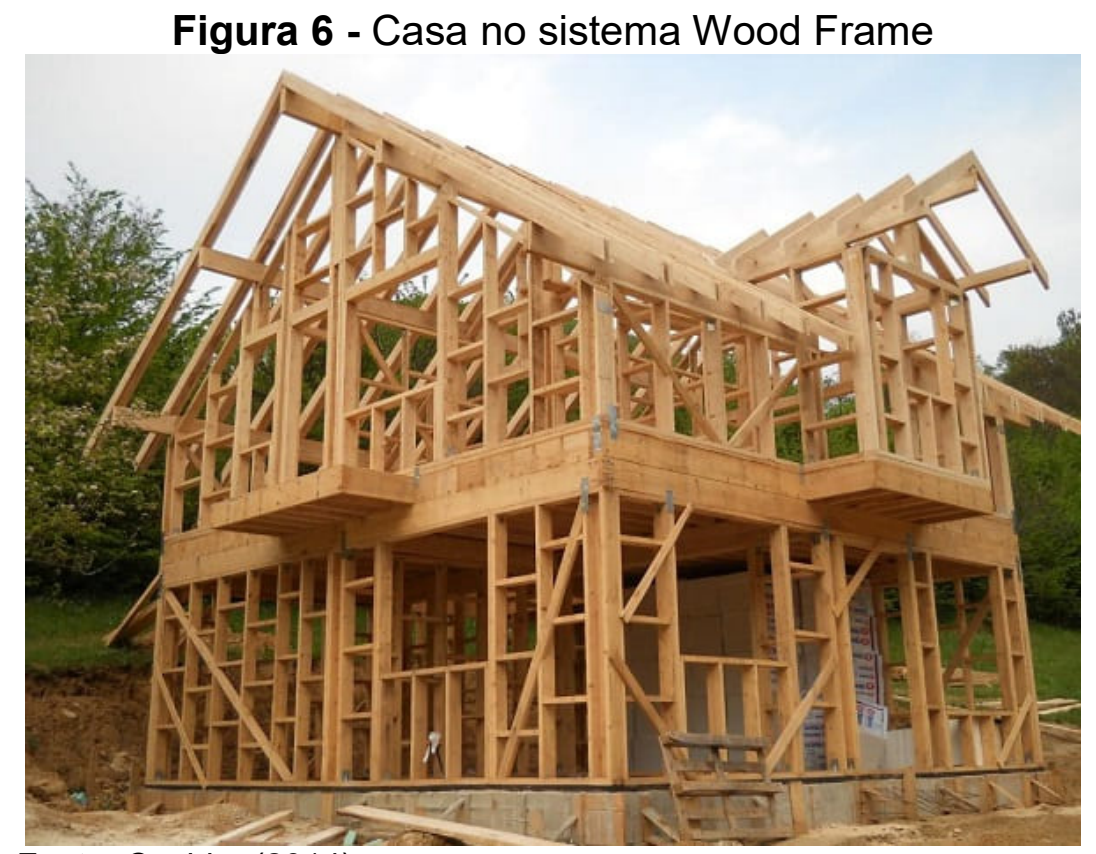

Fonte: Cachim (2014)

Desta maneira se torna válido estudar as características de edificações deste tipo para deste a fase projetual, se prever medidas de prevenção contra incêndio, levando em consideração as características deste material. Primeiramente, conforme exalta Pinto (2001, p. 22) é necessário "reconhecer simplesmente que não existe nenhum edifício aprova de fogo. Todos os objetos internos ao edifício queimam e a fumaça e calor gerado podem causar danos à edificação e perda de vidas, independente do material utilizado." Tal informação vai de encontro aos mitos criados sobre a falta de durabilidade e do comportamento ao fogo da madeira. Mello (2007, p.35) apud Calil (1999, p. 12) busca desmentir estas afirmações citando que

(...) uma peça de madeira exposta ao fogo torna-se um combustível para a propagação das chamas, porém, após alguns minutos, uma camada mais externa da madeira se carboniza tornando-se um isolante térmico, que retém calor, auxiliando, assim, na contenção do incêndio, evitando que toda peça seja destruída (...) Outra característica importante (...) é o fato de não apresentar distorção quando submetida a altas temperaturas, tal como ocorre com o aço, dificultando assim a ruína da estrutura (MELLO, 2007, p. 35 apud CALIL, 1999, p.12). 


\section{Pinto também descreve essa atuação da madeira como medida} preventiva, evitando estruturalmente que a edificação desabe. De acordo com ela

(...) a madeira, apresenta bom desempenho contra incêndio quando comparada a outros materiais estruturais. As peças robustas quando sob ação das chamas, formas uma camada de carvão isolante que impede a saída de gases inflamáveis e a propagação de calor para seu interior ( a velocidade de carbonização média da madeira é de $0,63 \mathrm{~mm} / \mathrm{min}$ ) o que justifica sua capacidade em manter a sustentação estrutural mesmo após terem sido expostas a altas temperaturas. Essa vantagem das peças robustas de madeira frente aos demais materiais deve ser especialmente considerada, pois um edifício ao se incendiar atinge facilmente temperaturas entre 700 a $900{ }^{\circ} \mathrm{C}$, o que representa a perda de resistência para materiais como o concreto e a perda da capacidade para carregamento por parte de todos os materiais metálicos ( alumínio, ferro, aço) caso não estejam devidamente protegidos, diferentemente das estrutura de madeira que sob certas condições mantém sua capacidade de suportar as cargas e por conseguinte permitir a ação dos sistemas de combate a incêndio (PINTO, 2001, p.22).

A Figura 7 ilustra o processo descrito por Pinto, com a camada externa de carvão. Desta maneira conclui-se que sim é viável construir edificações em madeira na atualidade e também que as mesmas podem ter um desempenho muito bom no combate ao incêndio desde que sejam bem projetadas.

Figura 7 - Viga de madeira carbonizada

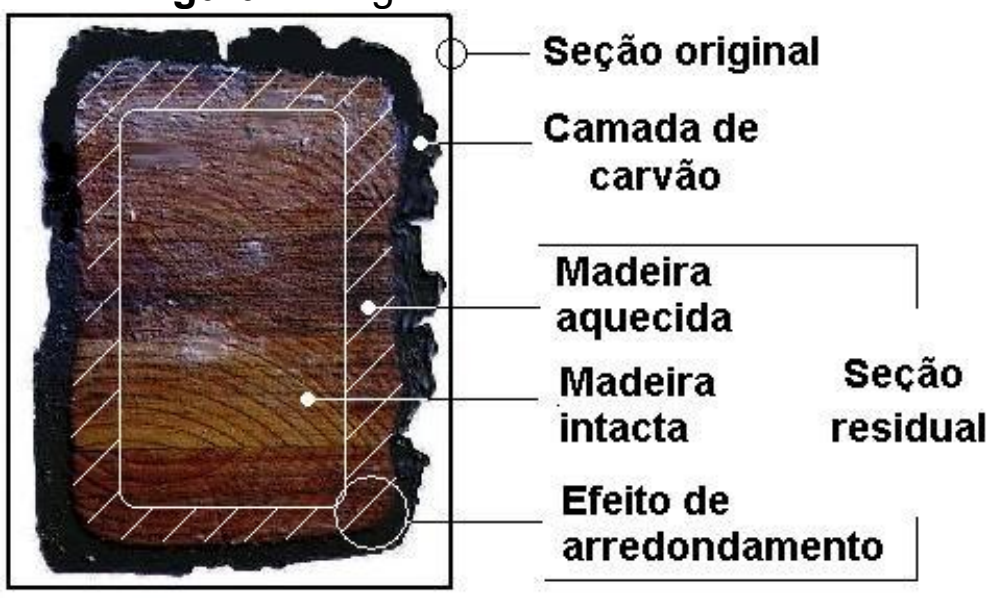

Fonte: Pinto (2001) 
Revista Científica do Corpo de Bombeiros Militar de Pernambuco

Artigo Publicado no Vol.06 N.17 - Edição Jul a Dez 2020 - ISSN 2359-4829

Versão on-line disponível em: http://www.revistaflammae.com

Algumas medidas construtivas podem ser exploradas já na etapa de

projeto para prever estas premissas conforme descrito por Pinto (2001) na

Tabela 7.

Tabela 7 - Sugestões construtivas para prevenção contra incêndio em residências em Madeira

EXEMPLOS DE ESTRATÉGIAS A SEREM UTILIZADAS EM PROJETO PARA CONCEPÇÃO DE EDIFICAÇÕES EM MADEIRA

Uma estrutura que prevê medidas de ventilação zenital pode
ser concebida na fase de elaboração do projeto residencial,
considerando meios mecânicos ou automáticos de exaustão
da fumaça que pode se acumular nos ambientes superiores
em casa de incêndio.

Dispositivo corta-fogo aplicado a área de passagem de dutos

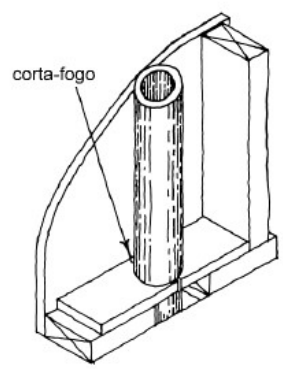

Dispositivo corta fogo aplicado ao forro

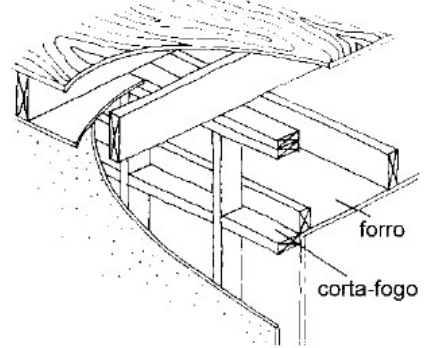

Dispositivo corta-fogo aplicado em parede divisória de edificação de múltiplos andares
Utilização de barreiras arquitetônicas que, quando expostas a condição de incêndio, impeça que o mesmo se propague e comprometa a segurança e integridade dos usuários e a integridade da propriedade. São localizadas entre elementos e/ou componentes, entre ambientes e entre edificações. Um exemplo de elemento deste tipo pode estar presente no forro por exemplo

Além disso para vigas apoiadas em paredes de alvenaria ou concreto, cuidados deve ser tomados a fim de evitar que em caso de incendio, o possivel colapso da viga não afete a parede. Desta forma prever um chafro na viga de madeira como ilustra a imagem abaixo de modo que a possivel 


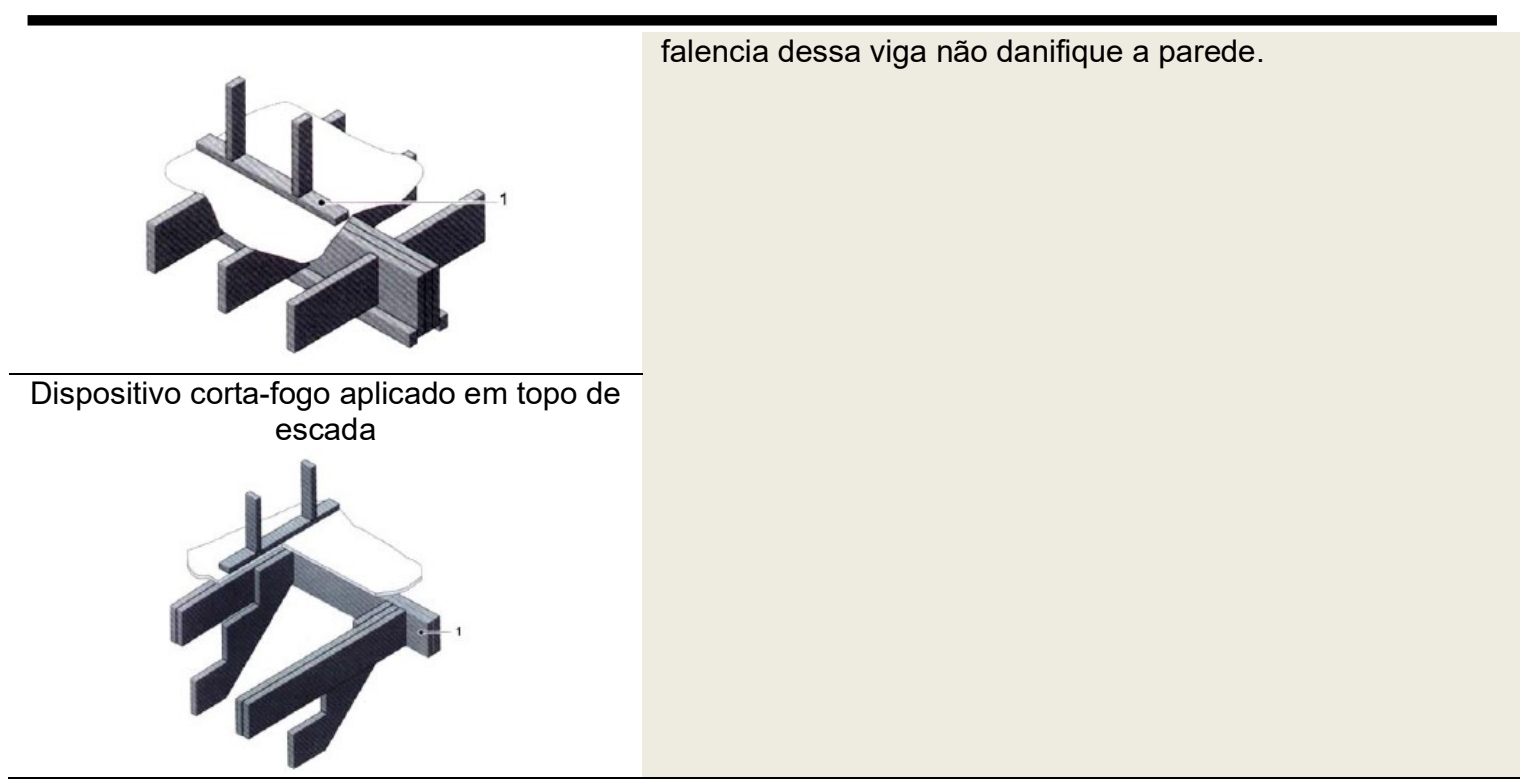

Junção pilar-viga de mandeira junto a parede separatória
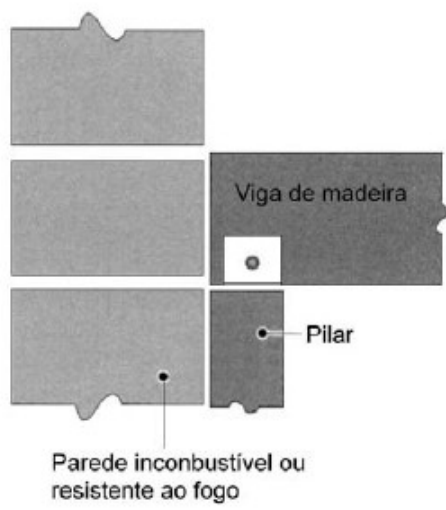

Além disso para vigas apoiadas em paredes de alvenaria ou concreto, cuidados deve ser tomados a fim de evitar que em caso de incendio, o possivel colapso da viga não afete a parede. Desta forma prever um chafro na viga de madeira como ilustra a imagem abaixo de modo que a possivel

Vida de madeira apoiada diretamente falencia dessa viga não danifique a parede.

sobre a parede de alvenaria

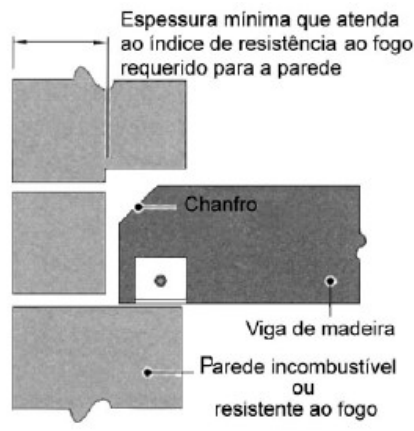

Uso de piso elevado de madeira

O piso quando feito no sistema de assoalho também exige alguns cuidados. A espessura dos barrotes deve ser de no mínimo $50 \mathrm{~mm}$ e a altura máxima de $300 \mathrm{~mm}$, com a utilização de dispositivos corta fogo a cada $10 \mathrm{~m}^{2}$ e além disto, devem ser apoiados em uma estrutura incombustível. 


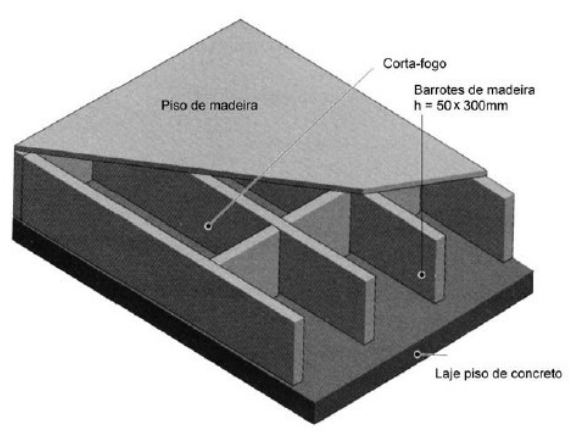

Fonte: Canadian Wood Council (1997) adaptado de Pinto (2001)

A tabela acima ilustra apenas uma pequena parcela das soluções projetuais que podem ser adotadas, aliadas aos itens citados na Tabela 8. Metodologias existem, o que falta são estudos mais consistentes para conciliar a prevenção contra incêndios a medidas projetuais em estruturas em madeira, e mais ainda, em como preservar e manter a salvo casas com esta característica construtiva.

\section{CONCLUSÃO}

Com o descrito, nota-se que as discussões acerca de medidas para prevenir incêndios em edificações de característica residencial vem aos poucos assumindo a verdadeira importância que possuem, não só em relação as características arquitetônicas, mas sim, para salvar as vidas residentes em seu interior. Porém, quando se refere a estruturas em madeira, principalmente as já edificadas, pouco material existe, além de diversas alegações relacionadas ao senso comum e mitos que rodeiam esse tipo de edificação.

Diante do material levantado se verifica que, se bem pensada e estruturada desde a etapa projetual, uma edificação em madeira pode conter sim, segurança contra incêndio, se métodos sobre estes aspectos forem estudados e implantados. Isso quando se trata de edificações novas, há muito ainda para ser explorado para lapidar os conhecimentos acerca da implantação 


\section{Revista FLAMMAE}

Revista Científica do Corpo de Bombeiros Militar de Pernambuco

Artigo Publicado no Vol.06 N.17 - Edição Jul a Dez 2020 - ISSN 2359-4829

Versão on-line disponível em: http://www.revistaflammae.com

de medidas preventivas contra incêndio em projetos de edificações em madeira.

Em contrapartida, em estruturas já edificadas, principalmente as mais antigas de origem vernacular concebidas pelos primeiros imigrantes europeus no sul do Brasil, há muito a se avaliar. Além da concepção dos problemas existentes na edificação, medidas preventivas devem ser implantadas para evitar danos tanto físicos quanto materiais. Na pesquisa ficou nítido parte dos motivos que colaboram para o surgimento de um acidente que resulte em fogo, e mais do que isso, algumas sugestões foram elencadas para tornar estas edificações mais seguras, com medidas preventivas de baixa complexidade de instalação. O que falta é bom senso da população que reside neste tipo de edificação em se atentar a estas problemáticas, e também a divulgação, por parte dos órgãos competentes para chamar atenção a esses possíveis sinistros orientando quais são as medidas preventivas adequadas a cada caso.

\section{REFERÊNCIAS}

ANVISA. Segurança contra incêndio em estabelecimentos assistenciais de saúde. Disponivel em: $<$ http://portal.anvisa.gov.br/documents/33852/271892/Manual+Seguran\%C3\%A $7 a+$ contra+Inc\%C3\%AAndio+em+Estabelecimentos+Assistenciais+de+Sa\%C3 \%BAde/b3d5c2ff-ffaa-4da3-a9e5-5cc9568ff8aa>. Acesso em: 22 jun 2020.

ARRUDA, José Roberto. Cartilha de incêndios florestais: causas, consequencias e como evitar. Governo do Distrito Federal. Disponivel em: < http://www.ibram.df.gov.br/wp-content/uploads/2018/02/CartilhaInc\%C3\%AAndios-Florestais-Causas-Consequ\%C3\%AAncias-e-ComoEvitar.pdf>. Acesso em 22 jun 2020.

BOGO, Amilcar J. Arquitetura em madeira em Santa Catarina: Patrimônio histórico e tipologia habitacional atual. Disponível em: $<$ https://www.vitruvius.com.br/revistas/read/arquitextos/18.208/6717>. Acesso em: 20 nov 2019. 
CACHIM, Paulo Bareto. Construção em madeira: a madeira como material de construção. Porto: Publindústria, 2014.

CARNIELETTO, Emiliano Colferai; CASTRO, Michele Giovanoni de; ARAÚJO, Rogério Lima. Analise da importância de medidas de segurança contra incêndio em residências unifamiliares. Disponivel em: $<$ https://e0d7bd2c$8 \mathrm{e} 8 \mathrm{c}-49 \mathrm{~d} 8-\mathrm{b} 8 \mathrm{~d} 1$ a3128f6947c7.filesusr.com/ugd/08765e_db6ca2623c1c44f1aa10d0242d51761f. pdf $>$. Acesso em: 22 jun 2020.

CBMSP. Orientações básicas para prevenção e combate a incêndios. Disponivel em: < http://www.piracicaba.sp.gov.br/upload/kceditor/files/ORIENTACOES\%20BASI CAS\%20DE\%20COMBATE\%20A\%20INCENDIO\%202018.pdf>. Acesso em: 22 jun 2020.

DALSSOTO, Eddy Roger; CARNEIRO, Gerson Luiz. Preocupações atuais sobre a proteção contra incêndio em patrimônios históricos e culturais. Universidade Tecnológica Federal do Paraná. Disponível em: $<$ https://semanaacademica.org.br/system/files/artigos/artigo_eddy_rogger_dals soto_-_utfpr.pdf>. Acesso em: 20 nov 2019.

DIETRICH, EIKE. Prevenção e combate a incêndio. Disponivel em: < https://iqm.unicamp.br/sites/default/files/Treinamento\%20contra\%20inc\%C3\%A Andio\%20Teoria\%20e\%20Pr\%C3\%A1tica_Eike\%20Dietrich.pdf>. Acesso em: 22 jun 2020.

FONSECA, J. J. S. Metodologia da pesquisa científica. Fortaleza: UEC, 2002.

FREIRE, Carlos Darci da Rocha. Projeto de prevenção contra incêndio (PPCl) de um prédio residencial no centro de Porto Alegre. Disponível em: < https://www.lume.ufrgs.br/bitstream/handle/10183/27114/000747270.pdf>. Acesso em: 22 jun 2020.

FUNDAÇÃO CATARINENSE DA CULTURA. Museu em destaque: museu do vinho Mário de Pellegrin. Disponível em: 


\section{Revista FLAMMAE}

Revista Científica do Corpo de Bombeiros Militar de Pernambuco

Artigo Publicado no Vol.06 N.17 - Edição Jul a Dez 2020 - ISSN 2359-4829

Versão on-line disponível em: http://www.revistaflammae.com

<http://www.cultura.sc.gov.br/noticias/patrimonio/14402-14402-museu-emdestaque-museu-do-vinho-mario-de-pellegrin>. Acesso em: 22 jun 2020.

HURTADO, José Edier Paz. Metodologia para levantamentos de cargas de Incêndio em Edificações Residenciais. Dissertação de mestrado. Disponível em: < https://repositorio.ufmg.br/bitstream/1843/BUOS-9MRFAZ/1/256.pdf>. Acesso em 22 jun 2020.

LAKATOS, Eva Maria; MARCONI, Marina da Andrade. Metodologia científica. São Paulo:Atlas, 2000.

MELLO, Roberto Lecomte de. Projetar em madeira: uma nova abordagem. Universidade de Brasília. Disponível em: <https://repositorio.unb.br/handle/10482/3133>. Acesso em: 20 nov 2019.

PINTO, Edna Moura. Proteção contra incêndio para habitações em madeira. Universidade de São Paulo. Disponível em:

$<$ https://www.teses.usp.br/teses/disponiveis/18/18131/tde-19052006114716/publico/CapaA.pdf>. Acesso em: 20 nov 2019.

SEITO, A. I. et al. A segurança contra incêndio no Brasil. São Paulo: Projeto, 2008.

SILVA, João Pereira. Risco de incêndio em patrimônio cultural: a importância das ações de manutenção preventiva. Universidade FUMEC. Disponível em: <http://ppg.fumec.br/ecc/wpcontent/uploads/2016/08/Disserta\%C3\%A7\%C3\%A3o-Final-Jo\%C3\%A3oPereira.pdf> Acesso em: 20 nov. 2019

STRIEDER, Roque. Diretrizes para elaboração de projetos de pesquisa. Joaçaba: Editora Unoesc, 2009. 